\title{
RSPO2 wt Allele
}

National Cancer Institute

\section{Source}

National Cancer Institute. RSPO2 wt Allele. NCI Thesaurus. Code C106068.

Human RSPO2 wild-type allele is located in the vicinity of $8 q 23.1$ and is approximately 184

$\mathrm{kb}$ in length. This allele, which encodes R-spondin-2 protein, is involved in both signal transduction and embryonic limb formation. 